\title{
Peran Ormawa dalam Membentuk Nilai-nilai Karakter di Dunia Industri (Studi Organisasi Kemahasiswaan di Politeknik Negeri Balikpapan)
}

\author{
Basri \\ Prodi Teknik Mesin Politeknik Negeri Balikpapan \\ basri.dahlan@poltekba.ac.id \\ Nawang Retno Dwiningrum \\ Prodi Tata Boga Politeknik Negeri Balikpapan \\ nawang.retno@poltekba.ac.id
}

\begin{abstract}
Abstrak
Kampus memiliki peran strategis dalam pengembangan sumber daya manusia melalui penyelenggaraan Tridharma Pendidikan Tinggi, yaitu pelaksanaan pendidikan dan pengajaran, penelitian dan pengabdian kepada masyarakat. Selain peran tersebut, perguruan tinggi vokasi memiliki tanggung jawab membekali peserta didik dengan nilai-nilai sesuai kebutuhan dunia kerja dan industri. Untuk dapat bekerja sesuai kebutuhan dunia kerja, selain penguasaan hard skill, juga penguasaan soft skill, karena dalam menjalankan profesinya selain menggunakan alat-alat teknologi juga melakukan interaksi sosial dengan sesama rekan kerja, atasan, dan mitra secara profesional. Untuk melatih mahasiswa dalam mengembangkan kemampuan intra personal dan interpersonal, selain diperoleh di ruang kuliah, juga melalui aktifitas organisasi kemahasiswaan (ormawa) yang ada di kampus seperti BEM, MPM, HMJ, dan UKM. Penelitian ini bertujuan untuk mengkaji peran ormawa dalam membentuk nilai-nilai karakter, dengan menganalisis indikator karakter dari pelaksanaan program kerja ormawa yang dilaksanakan. Di antara temuannya adalah tumbuhnya kemandirian, kreatifitas, tanggung jawab, kejujuran, akuntabilitas anggaran, dan manajemen waktu. Hasil penelitian ini menunjukkan bahwa ormawa memiliki peran dalam membentuk nilai-nilai karakter melalui aktifitas mahasiswa secara mandiri.
\end{abstract}

Kata kunci: dunia industri, mahasiswa, nilai-nilai karakter, ormawa

\begin{abstract}
Campus has a strategic role in the development of human resources through the implementation of Tridharma (three higher education roles), namely the implementation of education and teaching, research, and community service. In addition to this role, vocational colleges have the responsibility of equipping students with values according to the needs of the industry. To be able to work according to the needs of the workplace, not only to mastering hard skills, but also mastering soft skills, because in carrying out his profession in addition to
\end{abstract}


using technological tools also conduct social interaction with fellow colleagues, supervisors, and partners in a professional manner. To train students in developing intra-personal and interpersonal skills, in addition to being obtained in lecture halls, also through student organization activities (ormawa) on campus such as BEM, MPM, HMJ, and UKM. This study aims to examine the role of ormawa in shaping character values, by analyzing the character indicators of the implementation of ormawa's work program. Among the findings are the growth of independence, creativity, responsibility, honesty, budget accountability, and time management. The results of this study indicate that ormawa has a role in shaping character values through student activities independently.

Keywords: character values, industry workplace, students, students organization

\section{Pendahuluan}

Bangsa yang maju adalah bangsa yang memiliki sumber daya manusia yang berkualitas. Salah satu faktor yang menentukan kualitas pendidikan suatu bangsa adalah kualitas perguruan tinggi yang ada di negara tersebut. Perguruan tinggi vokasi di Indonesia, baik yang berbentuk Politeknik, Sekolah Tinggi, ataupun Institut, membekali lulusan dengan ilmu-ilmu terapan agar mampu bersaing di dunia kerja. Jika kualitas perguruan tinggi baik, maka akan mampu mencetak tenaga kerja yang terdidik dan terampil sehingga memiliki peluang yang besar untuk unggul dalam pasar tenaga kerja. Selain itu, perguruan tinggi memiliki peran yang penting dalam mencetak pemimpin dan pemikir suatu bangsa yang secara langsung dapat menentukan arah pembangunan negara di masa depan.

Perguruan tinggi memiliki tanggung jawab membekali mahasiswa dengan seperangkat keterampilan (hard skill) agar mampu bekerja sesuai dengan kebutuhan dunia kerja. Selain itu, lembaga pendidikan tinggi juga memiliki tanggung jawab menanamkan nilai-nilai karakter (soft skill) sebagai bekal peserta didik agar memiliki kepekaan dalam melakukan interaksi sosial dalam lingkungan kehidupannya baik dalam masyarakat, maupun dunia industri.

Proses pembentukan sikap profesi tidak hanya diperoleh di dalam ruangruang kuliah tetapi juga melalui organisasi, baik yang ada di tingkat institusi maupun yang ada di tingkat jurusan atau program studi. Setiap mahasiswa perlu mengikuti organisasi untuk mengembangkan diri sebagai bekal sebelum terjun di 
dunia kerja (industri). Mahasiswa sebagai civitas academica diposisikan sebagai insan dewasa yang memiliki kesadaran dalam mengembangkan potensi diri di Perguruan Tinggi untuk menjadi intelektual, ilmuwan, praktisi, atau profesional. Pengembangan bakat minat mahasiswa melalui kegiatan kokurikuler dan ekstra kurikuler sebagai bagian dari proses pendidikan dapat dilaksanakan melalui organisasi kemahasiswaan. ${ }^{1}$

Organisasi kemahasiswaan intern perguruan tinggi berfungsi sebagai sarana mahasiswa untuk menampung dan menyalurkan aspirasi mahasiswa, melalui kegiatan program kemahasiswaan. Pengembangan diri mahasiswa sebagai insan akademis, calon ilmuwan dan intelektual di masa depan, melalui pelatihan keterampilan organisasi, manajemen, dan kepemimpinan. Pembinaan dan pengembangan kader-kader bangsa yang berpotensi dalam melanjutkan kesinambungan pembangunan nasional, memelihara dan mengembangkan ilmu pengetahuan dan teknologi yang dilandasi oleh norma-norma agama, akademis, etika, dan wawasan kebangsaan. ${ }^{2}$

Jika melihat sejarah perjalanan bangsa Indonesia, kontribusi mahasiswa untuk kemajuan bangsa hampir tidak pernah lepas hingga kini. Jika mengingat sejarah pergerakan mahasiswa, dimulai dari kebangkitan Budi Utomo tahun 1908 dengan semangat menggelorakan agar bangsa Indonesia menjadi bangsa yang bersatu pada Sumpah Pemuda 1928, kemudian mahasiswa juga ikut serta dalam proses pembentukan negara kesatuan Republik Indonesia tahun 1945. Hal ini menunjukkan bahwa peran mahasiswa tidak hanya duduk di bangku kuliah dan memahami disiplin sesuai bidang ilmunya masing-masing, tetapi perlu dibekali dengan nilai-nilai sejak dini yang harus melekat dalam dirinya sebagai calon pemimpin bangsa agar memiliki nilai-nilai tanggung jawab, kedisiplinan, kejujuran, persatuan, cinta tanah air di manapun berada, baik di dunia kerja (industri) maupun dalam masyarakat luas.

${ }^{1}$ IPTEK, Sumber Daya. Undang-Undang Republik Indonesia No.12 Tentang Pendidikan Tinggi. Jakarta: Pendidikan Tinggi, Bab I Pasal 1314.

${ }^{2}$ Sudarsono, Juwono, Keputusan Mentri Pendidikan dan Kebudayaan. Jakarta:Kemdikbud. 1998, No. 155. 
Mahasiswa sebagai peserta didik memiliki potensi yang beragam. Untuk mengembangkannya, perlu pembinaan yang kontinyu, pengembangan iklim akademik, penyediaan fasilitas berbasis teknologi informasi, dan penyediaan sarana dan prasarana untuk pengembangan bakat dan minat yang dapat diakses mahasiswa melalui unit kegiatan seperti olah raga, seni, dan unit yang lainnya yang menjadi minat mahasiswa. ${ }^{3}$

Pengembangan mahasiswa tidak hanya diperoleh di ruang-ruang kuliah, tetapi juga diperoleh di dalam organisasi melalui aktivitas kemahasiswaan di kampus yang bertujuan untuk meningkatkan nilai intelektual dan integritas sebelum mahasiswa terjun langsung ke masyarakat. Pengembangan mahasiswa disesuaikan bakat dan minat, di mana mahasiswa diberikan kebebasan untuk memilih wadah yang tepat untuk memanfaatkan waktu luangnya sehingga tujuan dalam berorganisasi dapat tercapai.

Organisasi kemahasiswaan (ormawa) merupakan salah satu momentum kaderisasi yang berada di kampus dalam mengembangkan potensi mahasiswa. Sebagaimana yang tertuang di dalam undang-undang nomor 12 tahun 2012 tentang pendidikan tinggi yaitu pada Pasal 77 Ayat 1 sampai Ayat 3, bahwa organisasi kemahasiswaan menjadi wadah dalam mengembangkan bakat, minat, dan potensi pada mahasiswa, antara lain dalam bentuk sikap kepekaan, daya kritis, keberanian, rasa kebanggaan, tanggung jawab, serta kepemimpinan. Setiap kegiatan yang diadakan dalam organisasi tersebut akan berdampak secara tidak langsung kepada sikap mahasiswa seperti bagaimana proses rapat, diskusi, mengadakan bakti sosial, hingga mengasah kepedulian kepada masyarakat atau bertingkah laku terhadap diri sendiri, maupun teman sebaya.

Ormawa yang dimaksudkan dalam penelitian ini adalah organisasi internal kampus. Meski di sisi lain terdapat juga organisasi eksternal yang memberi peran, tetapi penelitian ini lebih fokus ke organisasi internal yang ada di kampus, yaitu Majelis Permusyawaratan Mahasiswa (MPM), Badan Eksekutif Mahasiswa (BEM), Himpunan Mahasiswa Jurusan (HMJ), serta berbagai Unit Kegiatan 
Kemahasiswaan (UKM) yang memfasilitasi bakat dan minat mahasiswa anggotanya.

Ormawa menjadi salah satu media yang tepat untuk membentuk sikap profesional. Dalam organisasi, setiap anggota mempunyai kewajiban untuk melaksanakan program kerja yang telah disusun berdasarkan visi dan misi organisasi. Hal ini mengandung makna organisasi mahasiswa sebagai latihan dalam menumbuhkan sikap disiplin, tanggung jawab, dan pekerja keras. Proses pengambilan keputusan secara musyawarah mufakat menjadi contoh yang kemudian melatih mahasiswa membentuk sikap toleransi, sabar, dan ikhlas menjalankan tugas berdasarkan kesepakatan bersama.

Beberapa organisasi internal kampus yang dapat menjadi wahana pengembangan minat dan bakat mahasiswa, meliputi pengembangan intelektual, sosial, kreatifitas, dan religius, di antaranya adalah: (1) Badan Eksekutif Mahasiswa (BEM) yang merupakan lembaga eksekutif mahasiswa yang mewadahi aspirasi mahasiswa di tingkat institusi; (2) Himpunan Mahasiswa Jurusan (HMJ) yang berada di tingkat jurusan keilmuan; dan (3) Unit Kegiatan Mahasiswa (UKM) yang merupakan wadah aktivitas mahasiswa untuk mengembangkan minat, bakat, dan keahlian tertentu seperti seni, pecinta alam, keagamaan, olahraga, dan lain sebagainya.

Keberadaan organisasi internal kampus memberikan pengaruh yang luar biasa terhadap pembentukan kualitas mahasiswa. Tentu ada konsekuensi tersendiri dari aktifitas organisasi mahasiswa. Hal itu terlihat dari pengorbanan yang dilakukan mahasiswa, mulai dari pengorbanan pikiran, waktu tenaga bahkan materi, seperti pengelolaan suatu kegiatan atau program kerja organisasi. Kegiatan organisasi mahasiswa dilakukan dengan menggunakan prinsip manajemen organisasi, yakni: perencanaan, pengorganisasian, kepemimpinan, dan pengendalian serta penggunaan sumber daya organisasi untuk mencapai tujuan yang telah ditetapkan. ${ }^{4}$ Konsep tersebut sesungguhnya mengajarkan mahasiswa bagaimana melakukan manajemen dengan baik. Dalam menjalankan roda

${ }^{4}$ Fathor Rachman, "Manajemen Organisasi Dan Pengorganisasian Dalam Perspektif AlQuran Dan Hadith," Studi Keislaman 1, no. 2 (2015): 291-323. 
organisasi diperlukan juga manajemen waktu yang baik agar tugas pertama dan utama mahasiswa, yaitu kuliah, tidak menjadi terabaikan. Dalam proses inilah secara tidak sadar mahasiswa telah berlatih mengembangkan diri, mengatur waktu, berkomunikasi dengan orang banyak, merangsang kepekaan sosial terhadap masyarakat, juga dilatih menjadi pemimpin yang amanah dan bertanggungjawab.

Tujuan penelitian ini membahas bagaimana peran organisasi kemahasiswaan dalam membentuk nilai-nilai karakter mahasiswa sesuai standar dunia kerja atau industri, di mana kebutuhan dunia kerja dewasa ini selain penguasaan hard skill juga penguasaan soft skill. Oleh karena itu, perguruan tinggi vokasi selain membekali lulusan dengan penguasaan keterampilan agar mampu bekerja sesuai dengan profesinya juga harus membekali kemampuan soft skill agar memiliki kemampuan dalam melakukan interaksi sosial dengan sesama rekan kerja, atasan, maupun stakeholder, sehingga industri produktif dalam memberikan layanan.

Penelitian ini berorientasi kepada peran organisasi kemahasiswaan dalam membentuk nilai-nilai karakter mahasiswa. Beberapa penelitian terdahulu yang relevan dengan peran organisasi kemahasiswaan dari berbagai sudut pandang seperti Penelitian Faisal $^{5}$ yang menekankan mengenai peran Ormawa dalam meningkatkan mutu pembelajaran Arab, seperti: kemahiran mendengar, berbicara, membaca dan menulis melalui kegiatan Yaumil Arabi (hari berbahasa Arab) seminar tentang kebahasaan tingkat mahasiswa, jurnalistik, kaligrafi, debat, puisi, menyanyi dalam bahasa Arab, perlombaan dan pertandingan baik lokal, nasional, dan internasional. Penelitian Purba ${ }^{6}$ yang menekankan mengenai peran organisasi himpunan mahasiswa program studi (HMPS) dalam mengembangkan karakter kepemimpinan mahasiswa seperti keberanian mengemukakan pendapat,

${ }^{5}$ Faisal Hendra, "Peran Organisasi Mahasiswa Dalam Meningkatkan Mutu Pembelajaran Keterampilan Berbahasa Arab," Arabiyat : Jurnal Pendidikan Bahasa Arab Dan Kebahasaaraban 5, no. 1 (2018): 103-20, https://doi.org/10.15408/a.v5i1.7480.

6 Leony Sanga Lamsari Purba and Elisa Natalia Sibarani, "Peran Organisasi Himpunan Mahasiswa Program Studi Dalam Membentuk Karakter Kepemimpinan Calon Guru Kimia," Jurnal Pendidikan Kimia 9, no. 1 (2017): 259-64, https://doi.org/10.24114/jpkim.v9i1.6190. 
kemampuan berdiskusi, dan kepemimpinan. Penelitian Hidayah $^{7}$ yang lebih menekankan pada Peran BEM UNY dalam meningkatkan civic skills aktivis BEM sebagai mitra yang baik bagi UNY yang memberikan kritik dan saran membangun kepada rektor untuk kesejahteraan mahasiswa UNY dan sebagai fasilitator dalam menyampaikan aspirasi kepada rektor.

Dari beberapa penelitian organisasi kemahasiswaan terdahulu, didapati arah dan spesifikasinya yang berbeda dengan yang ada dalam penelitian ini. Di sini, lebih spesifik kepada pengembangan nilai-nilai karakter dengan menekankan perilaku yang aplikatif dan berorientasi kepada profesi pelayanan kepada orang lain, baik penampilan, perkataan, penggunaan bahasa, keramahan, menerima orang lain, kesungguhan dalam bekerja, kemampuan menahan diri, dan ketelitian.

Pendekatan dalam penelitian ini adalah pendekatan kualitatif deskriptif, yaitu model penelitian dengan menggunakan pendekatan alamiah dalam mencari dan menemukan pengertian atau pemahaman tidak berdasarkan angka-angka dalam pengolahan datanya. ${ }^{8}$ Sumber data penelitian ini adalah organisasi kemahasiswaan yang ada di Politeknik Negeri Balikpapan, terdiri dari dari 1 lembaga legislatif (MPM), 1 lembaga eksekutif (BEM), perwakilan mahasiswa dari 7 himpunan mahasiswa jurusan, dan 4 mahasiswa dari unit-unit kegiatan kemahasiswaan.

Dalam proses pengumpulan data dan penggalian informasi, peneliti melakukan studi literer dari berbagai jurnal kontemporer maupun buku-buku yang berhubungan dengan organisasi kemahasiswaan dan perannya di perguruan tinggi. Terkait dengan program-program yang mendukung pembentukan nilainilai karakter mahasiswa penulis menggali data dengan melakukan wawancara mendalam kepada 13 (tiga belas) orang pengurus ormawa yang menjadi objek yang diamati untuk memperoleh informasi. Dalam proses wawancara peneliti menggunakan pedoman wawancara dan untuk memastikan akurasi data terkait

\footnotetext{
${ }^{7}$ Yayuk Hidayah and Sunarso Sunarso, "Penguasaan Civic Skills Aktivis Badan Eksekutif Mahasiswa (Studi Di Universitas Negeri Yogyakarta)," Harmoni Sosial: Jurnal Pendidikan IPS 4, no. 2 (November 7, 2018): 153-64, https://doi.org/10.21831/hsjpi.v4i2.9862.

${ }^{8}$ Moeloeng, Metodologi Penelitian Kualitatif (Bandung : Remaja Rosda Karya, 2012), 5.
} 
program-program yang dilakukan mahasiswa yang dapat mendukung pembentukan karakter mahasiswa. Penulis juga mengumpulkan data secara triangulasi dengan memeriksa dokumen-dokumen laporan kegiatan kemahasiswaan baik yang ada di Bagian Akademik Kemahasiswaan maupun dokumen yang dimiliki ormawa yang diamati. Dari pengumpulan data kemudian penulis melakukan klasifikasi data sesuai kelompoknya kelompoknya kemudian disusun dan dideskripsikan. Proses pengolahan data dengan mengacu kepada pengolahan analisis data model interaktif Miles dan Huberman ${ }^{9}$ dalam Gambar 1.

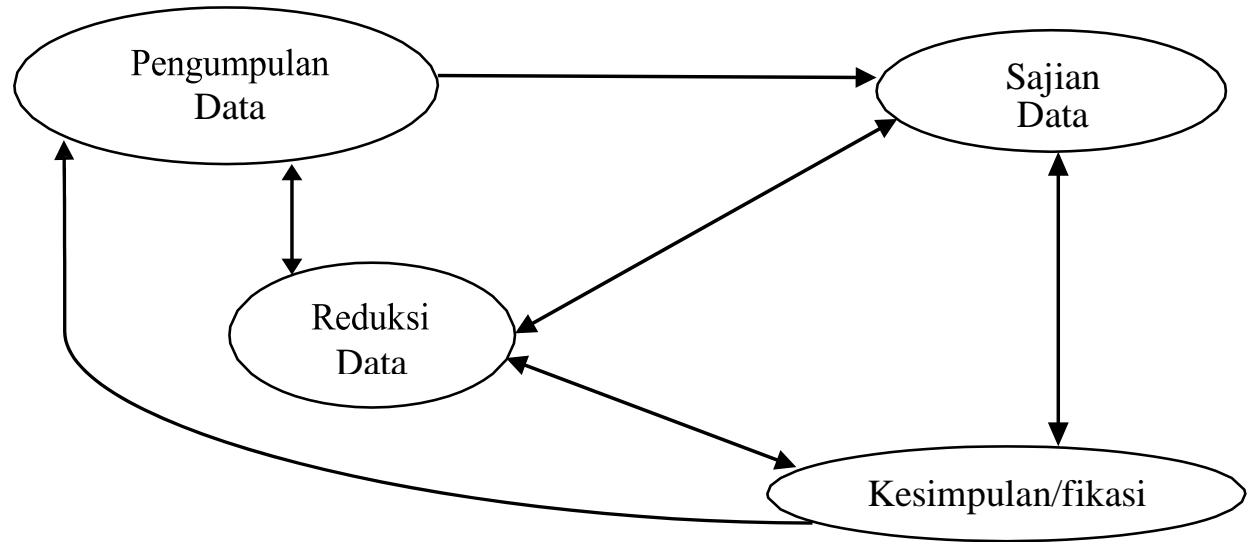

Gambar 1. Proses pengolahan data

\section{Peran Ormawa dalam Membentuk Nilai-nilai Karakter di Dunia Industri}

Karakter adalah nilai-nilai perilaku manusia yang berhubungan dengan Tuhan Yang Maha Esa, diri sendiri, sesama manusia, lingkungan, dan kebangsaan yang dimanifestasikan dalam pikiran, sikap, perasaan, kata-kata, dan tindakan berdasarkan norma agama, hukum, tata krama, budaya, dan adat istiadat. ${ }^{10}$ Karakter yang baik tentu merupakan hal yang wajib dimiliki oleh seluruh manusia termasuk mahasiswa yang berada di perguruan tinggi sebagai modal awal dalam menjalani kehidupan sosial. Pendidikan tinggi vokasi seperti Politeknik, Akademi, dan Institut, selain menyiapkan lulusannya untuk bidang

${ }^{9}$ Sugiyono,Metode Penelitian Kuantitatif Kualitatif dan R\&D (Bandung, 2010), 247.
${ }^{10}$ Muhamad Asvin Abdur Rohman, "Pendidikan Karakter Di Sekolah Menengah Pertama
): Teori, Metodologi Dan Implementasi," QALAMUNA: Jurnal Pendidikan, Sosial, Dan Agama 11, no. 2 (2019): 265-86. 
ilmu-ilmu terapan untuk siap kerja di dunia industri, juga membekali peserta didik dengan keterampilan (hard skil dan soft skill) sesuai dengan tuntutan kebutuhan dunia industri. Oleh karena itu, lembaga pendidikan tinggi tidak hanya bertanggung jawab terhadap kompetensi dan pengetahuan mahasiswa sebagai bekal sebelum terjun ke dunia kerja dan industri, akan tetapi institusi pendidikan tinggi memiliki tanggung jawab untuk membekali peserta didik dengan pengembangan sikap sesuai dengan kebutuhan dunia industri agar mampu bekerja secara profesional. ${ }^{11}$

Kebutuhan dunia industri membutuhkan tenaga-tenaga professional yang siap kerja yaitu yang memiliki kompetensi tertentu sesuai bidang keahliannya $(s k i l l)$. Selain kompetensi tersebut, mahasiswa harus memiliki kemampuan soft skill baik interpersonal skill seperti kepemimpinan, kemampuan negosiasi dan komunikasi, dan motivasi maupun kemampuan intrapersonal skill seperti kemampuan berpikir kreatif, kemampuan menajemen waktu, manajemen emosi, manajemen stres yang disertai penentuan prinsip, dan tujuan hidup.

Berdasarkan dokumen Kementerian Pendidikan Nasional Direktorat Jenderal Pendidikan tinggi tentang nilai karakter mahasiswa, pelaksanaan nilainilai tersebut di ormawa adalah sebagai berikut: ${ }^{12}$

\section{Religius}

Sikap religius salah satu indikator mahasiswa memiliki kepribadian yang baik sebagai manifestasi dari kesadaran jiwa sebagai wujud penghayatan terhadap nilai-nilai berdasarkan norma-norma agama yang dianut. Hampir semua mahasiswa yang aktif di organisasi kemahasiswaan menghayati terhadap nilai-nilai ajaran agama yang dianutnya. Hal ini terlihat dari kesadaran mahasiswa dalam melaksanakan ibadah salat khususnya yang beragama Islam ketika waktu salat zuhur mereka langsung melakukan salat karena mereka sadar bahwa selain menjaga hubungan dengan sesama

\footnotetext{
${ }^{11}$ Mujib Ubaidillah, "Pembelajaran Berbasis Proyek Untuk Mengembangkan Ensiklopedia Berbasis Bioedupreneurship," JURNAL PENDIDIKAN SAINS (JPS) 05 (2017): 32-40.

12 Kementerian Pendidikan Nasional Direktorat Jenderal Pendidikan Tinggi Naskah Akademik Pendidikan Karakter di Perguruan Tinggi. 2011.
} 
manusia hubungan dengan Tuhan juga harus terjaga.

Mayoritas mahasiswa beragama Islam, sehingga secara otomatis yang ikut dalam organisasi rata-rata beragama Islam. Namun demikian, dalam merekrut calon anggota organisasi secara umum tidak ada yang mempertimbangkan latar belakang agama. Tetapi didasarkan pada keinginan dari mahasiswa calon anggota untuk bergabung dalam organisasi untuk selanjutnya melakukan registrasi keanggotaan, dengan dasar itu setiap anggota diseleksi dengan tes minat bakat. Dari hasil seleksi inilah akan terlihat calon anggota yang memang sungguh-sungguh untuk mejadi anggota organisasi sesuai pilihannya. Untuk menjadi anggota organisasi internal kampus harus sungguh-sungguh mengikuti sehingga dalam pengembangan diri sesuai dengan bakat minat memang didorong untuk pengembangan kompetensi diri.

2. Jujur

Sikap seseorang yang menunjukkan perbuatan dan perkataanya sejalan berkata apa adanya tidak menutup-nutupi keadaan yang sesungguhnya, salah satu indikasi pribadi yang baik menunjukkan sikapnya yang benar. Perilaku ini akan terbentuk dari sikap seseorang yang memang terbiasa berlaku apa adanya meski hal-hal kecil sekalipun. Dunia kerja atau industri membutuhkan tenaga profesional yang mampu bekerja di bidangnya dan memiliki integritas baik. Orientasi sebuah perusahaan adalah profit selain mengelola sumber daya manusia, keuangan juga mengelola sumber daya alat. Pengelolaan sumber daya tersebut perlu dikelola oleh orang yang memiliki pengetahuan dan integritas baik, agar perusahaan produktif dalam menjual jasa kepada pelanggan sehingga mendapatkan keuntungan.

Dari hasil pengamatan, kegiatan organisasi membentuk kejujuran seperti membuat laporan tertulis pada setiap kegiatan yang telah dilaksanakan sebagai wujud pertanggungjawaban penggunaan anggaran yang disertai bukti-bukti yang valid. Pengurus organisasi kampus dari 16 organisasi kemahasiswaan yang diamati mensyaratkan laporan 
pertanggungjawaban harus ada setiap berakhir kegiatan sebagai bentuk pertanggungjawaban moral kepada semua pihak, baik kepada rektorat yang menyediakan dana DIPA maupun kepada pihak sponsor/donatur. Selain itu, pengurus organisasi dan jajarannya mensyaratkan laporan pertanggungjawaban sebagai dokumen yang bisa ditelusuri dan bisa dicontoh oleh adik-adik junior di masa yang akan datang bila melaksanakan kegiatan yang sejenis.

3. Disiplin

Disiplin identik dengan tepat waktu, ketaatan, dan keteraturan. Perilaku disiplin harus ditanamkan kepada seseorang sejak kecil hingga dapat melalui kebiasaan yang tertanam dalam diri seseorang baik dalam keluarga, lembaga pendidikan formal, maupun lewat organisasi.

Berdasarkan hasil pengamatan dokumen dan hasil wawancara dengan pengurus mahasiswa, dalam menjalankan roda organisasi kemahasiswaan, perilaku disiplin terbentuk melalui kesepakatan jadwal waktu pelaksanaan program kerja yang bertujuan untuk menjadi acuan bersama dalam mengimplementasikan program sesuai rencana dengan tepat waktu. Selain itu mereka juga harus memiliki komitmen bersama untuk menghadiri rapatrapat koordinasi meski undangannya terkadang hanya lewat grup WhatsApp tetapi tetap semangat menghadiri rapat dengan tepat waktu. Tampak juga dalam wujud panitia pelaksana membuat laporan kegiatan yang telah dilaksanakan. Semua aktifitas organisasi secara alami membentuk kebiasaan dan pengalaman mahasiswa dalam berorganisasi sehingga akan menjadi pengalaman tersendiri ketika berada di tempat yang lain.

\section{Kerja Keras}

Kerja keras adalah kegiatan yang dilakukan dengan sungguh-sungguh tidak mengenal lelah sebelum target tercapai, mengutamakan kepuasan hasil pada setiap kegiatan yang dilakukan. Sikap kerja keras terukur dari kegiatan yang dilakukan oleh mahasiswa, seperti penyusunan program secara bersama, pengelolaan program dan pengaturan waktu luang untuk kegiatan koordinasi 
baik rapat resmi maupun sekedar koordinasi lewat media daring dan menjalankan program kerja kerja organisasi dengan baik. Kegiatan yang melibatkan mahasiswa lintas program studi yang berbeda waktu kuliah teori atau jadwal praktik masing-masing prodi, dan membentuk kepanitiaan untuk merealisasikan pelaksanaan program kerja bersama juga merupakan dua hal yang memerlukan konsistensi yang tinggi. Dalam berkegiatan pun menyusun proposal secara tertulis dan menyampaikan kepada instansi atau pihak-pihak yang membantu, membuat laporan kegiatan dan pertanggungjawaban anggaran yang semuanya ini tidak mudah tanpa dukungan dan semangat kerja keras dan kerja ikhlas dari semua pihak untuk sebuah harapan agar kegiatan organisasi berjalan dengan sukses.

\section{Kreatif}

Kreatif adalah kemampuan yang dimiliki seseorang maupun kelompok untuk melakukan terobosan atau pendekatan tertentu dalam memecahkan permasalahan dengan cara yang berbeda atau kemampuan seseorang dalam menciptakan hal-hal baru baru yang berbeda dari yang sudah ada sebelumnya. Sikap kreatif mahasiswa harus dibangun sejak dini sebagai bekal sebelum terjun ke dunia industri dengan bekal keterampilan diharapkan memiliki kemampuan kerja sehingga mampu mengembangkan dirinya. Dengan keterampilan yang dimiliki dianggap sebagai penentu di era revolusi industri 4.0 seperti kemampuan beradaptasi, pola pikir, kewirausahaan yang kritis dan inovatif, akuntabel, didorong oleh tujuan dan semangat serta keterampilan lainnya yang dianggap relevan untuk dipekerjakan dan siap bekerja. ${ }^{13}$

Organisasi kemahasiswaan melatih mahasiswa memiliki sikap kreatif dalam mengelola organisasi, menyusun program kreatif sesuai dengan kebutuhan mahasiswa, mendesain model-model pertemuan agar diminati mahasiswa dengan mengubah model pertemuan dari yang biasanya

\footnotetext{
${ }^{13}$ Unung Vera Wardina, Nizwardi Jalinus, and Lise Asnur, "KURIKULUM PENDIDIKAN VOKASI PADA ERA REVOLUSI INDUSTRI 4.0," Jurnal Pendidikan 20, no. 1 (March 28, 2019): 82-90, https://doi.org/10.33830/jp.v20i1.240.2019.
} 
dilaksanakan di ruang-ruang kelas atau di sekretariat BEM menjadi di tempat-tempat santai dan menyenangkan mahasiswa seperti di kafe.

6. Mandiri

Sikap mandiri adalah perilaku/sikap mental yang memungkinkan seseorang untuk bertindak bebas, benar, dan bermanfaat; berusaha melakukan segala sesuatu dengan jujur dan benar atas dorongan dirinya sendiri dan kemampuan mengatur diri sendiri, sesuai dengan hak dan kewajibannya. Dengan sikap ini diharapkan dapat menyelesaikan masalah-masalah yang dihadapinya dan bertanggung jawab terhadap segala keputusan yang diambil melalui segala pertimbangan sebelumnya.

Kemandirian merupakan suatu sikap yang diperoleh secara kumulatif melalui proses yang dialami seseorang dalam perkembangannya, di mana dalam proses menuju kemandirian, individu belajar untuk menghadapi berbagai situasi dalam lingkungan sosialnya sampai ia mampu berpikir dan mengambil tindakan yang tepat dalam mengatasi setiap situasi. Aktivitas bersama membantu anak untuk menanamkan cara berfikir dan bersikap di masyarakat dan menjadikannya sebagai caranya sendiri. Orang dewasa (teman sebaya yang lebih tua) seharusnya membantu mengarahkan dan mengorganisir proses pembelajaran anak sehingga mampu menguasai dan menginternalisasi secara mandiri. ${ }^{14}$ Mahasiswa sejak memasuki bangku perkuliahan sudah dilatih mandiri seperti mengerjakan tugas kuliah, tidak bergantung tetapi tetap dapat berinteraksi sosial dengan orang lain, sehingga menghasilkan sesuatu yang berguna dan bermanfaat baik. Hal ini tentu berbeda jauh dengan ketika masih berada di bangku sekolah lanjutan atas (SLTA) yang terkesan lebih banyak dituntun. Mahasiswa pendidikan vokasi seperti Politeknik, Akademi atau Institut diharapkan memiliki kemandirian yang lebih dibandingkan dengan mahasiswa pada umumnya karena mereka sudah dibekali dengan keterampilan tertentu yang dibutuhkan sesuai dengan kebutuhan dunia industri sehingga harus lebih mandiri. $31-46$.

${ }^{14}$ Rika Sa'diyah, "Pentingnya Melatih Kemandirian Anak," Jurnal KORDINAT 16 (2017): 
Ciri-ciri seseorang dikatakan mandiri adalah secara fisik mampu bekerja sendiri, secara mental dapat berpikir sendiri, secara kreatif mampu mengekspresikan gagasannya dengan cara yang mudah dipahami, dan secara emosional kegiatan yang dilakukannya dipertanggungjawabkan sendiri. ${ }^{15}$ Semangat kemandirian terukur dari semangat mereka dalam melaksanakan tugas organisasi yang diikuti mahasiswa seperti penyusunan program kerja, pencarian sponsor pendukung kegiatan dan pelaksanaannya, semuanya dilakukan atas inisiasi mahasiswa meski tetap ada komunikasi dengan dosen pembimbing. Menyusun dan mengelola program kerja secara mandiri dan melaksanakan program kerja bersama team work mengelola kegiatan dengan baik, membuat skala prioritas program kerja mendahulukan kegiatan yang lebih mudah pelaksanaan serta pembiayaannya, sedangkan program kegiatan yang agak berat pelaksanaannya ditunda agar persiapannya lebih baik.

\section{Semangat Kebangsaan}

Sikap yang menunjukkan kesadaran seseorang untuk menunjukkan kesetiaan kepada negara atau bangsanya. Setiap warga negara Indonesia memiliki tanggung jawab untuk mencintai tanah airnya. Mahasiswa sebagai warga negara Indonesia dan sekaligus penerus estafet kepemimpinan bangsa untuk membuktikan kecintaan kepada negaranya dengan belajar sungguhsungguh menemukan sesuatu yang bermanfaat untuk bangsanya. Semangat kebangsaan mahasiswa terlihat dari hasil-hasil pemikiran dan kegiatan yang positif dan berguna untuk bangsa seperti seminar lingkungan oleh UKM Himpunan Mahasiswa Pecinta Alam. Kegiatan ini bertujuan untuk memperluas wawasan kebangsaan dan kecintaan kepada tanah air, di mana mahasiswa sebagai kader bangsa harus menjaga dan melestarikan lingkungan sebagai tempat hunian manusia di bumi sebagai wujud pengabdian kepada masyarakat. Ada juga kegiatan uji emisi untuk mendeteksi gas buang kendaraan lalu lintas dalam kota Balikpapan yang

\footnotetext{
${ }^{15}$ Rika Sa'diyah., 37.
} 
mengandung racun dalam upaya mencegah pencemaran lingkungan yang dapat membahayakan manusia yang diselenggarakan oleh HMJ Teknik Mesin. Ada juga pemberian bantuan sosial kepada buruh industri yang bekerja di malam hari sebagai bentuk rasa solidaritas kepada sesama anak bangsa yang dilaksanakan oleh HMJ Elektronika, HMJ Perhotelan, dan LDK. Pada umumnya, kegiatan yang dilakukan mahasiswa ini berguna dalam mendukung pelayanan pemerintah kepada masyarakat.

\section{Cinta Tanah Air}

Cinta tanah air, yakni munculnya rasa cinta oleh warga negara untuk negaranya dengan bersedia mengabdi, berkorban, memelihara persatuan dan kesatuan, melindungi tanah air dari segala ancaman, gangguan, dan tantangan yang dihadapi oleh negara. Setiap warga negara Indonesia memiliki tanggung jawab untuk menjaga persatuan dan kesatuan bangsa agar terhindar dari perpecahan yang dapat merusak keutuhan bangsa. Mahasiswa sebagai aset pembangunan bangsa harus menjadi pelopor dalam menjaga persatuan dan kesatuan. Di antaranya yaitu dengan kegiatan yang bekerja sama dengan Depo Pendidikan Kejuruan (DODIKJUR) TNI menyelenggarakan latihan kedisilinan dasar dan bela negara bagi mahasiswa baru. Dengan demikian, ilmu dan pengalaman belajarnya bermanfaat bagi dirinya maupun masyarakat, sehingga bisa berkonstribusi langsung terhadap pertumbuhan ekonomi sesuai dengan profesi yang disemangati oleh rasa cinta kepada tanah air.

9. Memberikan apresiasi

Apresiasi adalah tindakan yang menunjukkan rasa senang dan bekerja sama dengan orang lain. Sikap dan tindakan yang mendorong dirinya untuk menghasilkan sesuatu yang berguna bagi masyarakat, dan mengakui,serta menghormati keberhasilan orang lain. Saling menghargai satu sama lain dalam kehidupan bermasyarakat, berbangsa dan bernegara untuk ditumbuhkembangkan sejak dini agar tercipta suasana yang harmonis, damai, dan tentram antara satu warga negara dengan warga negara yang 
lainnya dengan tidak melihat latar belakang. Meski berbeda-beda suku agama dan budaya masing-masing, tetapi semangat menghargai harus dijunjung tinggi karena Allah telah menakdirkan manusia berbeda antara satu dengan yang lainnya dalam keragaman.

Semangat saling menghargai dalam kehidupan tercermin dengan memberi motivasi kepada sesama warga yang telah berkarya nyata yang berguna bagi orang lain. Sikap saling menghormati dan menghargai pada mahasiswa tercermin dari setiap selesai melaksanakan kegiatan atau program kerja, selalu diberikan penyemangat dengan ucapan terima kasih atas keberhasilan dalam menyelenggarakan salah satu program kerja. Ucapan terima kasih ini biasanya disampaikan oleh ketua UKM pada saat pembubaran panitia.

\section{Bersahabat/Komunikatif}

Persahabatan adalah istilah yang menggambarkan perilaku kerja sama dan saling mendukung antara dua orang atau lebih entitas sosial. Sahabat adalah orang yang memperlihatkan perilaku yang berbalasan dan reflektif. Pertemanan akan terjalin jika ada rasa saling memahami, saling mengerti, dan saling menjaga perasaan antara satu dengan yang lainnya sehingga terbina suasana keakraban dan komunikasi yang baik.

Ada beberapa kemampuan yang harus dikuasai dalam komunikasi interpersonal agar terjalin komunikasi yang baik menurut Suranto AW dalam Kamaruzzaman, di antaranya: ${ }^{16}$

a. Keterampilan berbicara

b. Keterampilan bertanya

c. Keterampilan membuka pintu komunikasi

d. Keterampilan menjaga sopan santun

e. Berani meminta maaf pada saat merasa bersalah

16 Kamaruzzaman Kamaruzzaman, "ANALISIS KETERAMPILAN KOMUNIKASI INTERPERSONAL SISWA,” JURNAL KONSELING GUSJIGANG 2, no. 2 (October 28, 2016), https://doi.org/10.24176/jkg.v2i2.744. 
f. Cepat tanggap dan bertanggung jawab

g. Perhatian dan kepedulian

h. Memiliki empati

i. Keterampilan mendengarkan

Organisasi kemahasiswaan merupakan tempat bertemunya antara mahasiswa yang satu dengan mahasiswa lainnya dengan latar belakang sosial dan karakter yang berbeda. Mereka berkumpul di basecamp ataupun di grup WhatsApp untuk membahas program untuk mencapai tujuan. Dalam proses inilah, akan tumbuh sikap saling menghormati, saling menghargai, bergotong royong, dan bahu membahu untuk menyukseskan kegiatan kemahasiswaan seperti penyusunan program kerja, pencarian dana, dan sebagainya. Hal ini bisa terjadi karena telah terjalin komunikasi yang baik antara satu dengan yang lain dalam melaksanakan tugas dan tanggung jawab organisasi yang diamanahkan.

11. Cinta Damai

Sikap dan tindakan membuat orang lain merasa senang dan aman atas kehadirannya. Cinta damai terwujud dalam kehidupan bermasyarakat dengan selalu menjaga kerukunan menahan diri dari perkataan dan perbuatan yang dapat menimbulkan kebencian, permusuhan, apalagi kekerasan. Cinta damai tercermin dalam hidup saling menghormati dan menghargai satu sama lain, meskipun berbeda suku, agama, adat istiadat, dan budaya. Kerukunan terwujud jika setiap warga negara Indonesia memandang perbedaan sebagai anugerah Allah SWT. dan bukan menjadi sumber perpecahan. Indonesia merupakan negara yang khas dengan keragaman dengan semboyan Bhinneka Tunggal Ika (berbeda-beda tetapi tetap satu jua). Di sisi lain, ormawa menjadi sarana menghimpun mahasiswa dari berbagai latar belakang untuk tujuan yang sama yang ingin dicapai. Mereka bersama-sama melakukan kegiatan yang berguna bagi orang lain dengan tidak menonjolkan suku ataupun agama, tetapi disemangati oleh visi misi dan kecintaan kepada almamaternya. Kegiatan yang dilakukan ormawa 
tersebut berorientasi untuk membentuk cinta kepada lingkungan dan kepada sesama manusia. Hasil dari pemikiran mereka diharapkan memberi kontribusi positif bagi orang lain sehingga akan tumbuh sikap saling menghormati sesama dalam kehidupan bermasyarakat.

12. Peduli Sosial

Manusia sebagai makhluk sosial saling membutuhkan antara satu dengan yang lain karena manusia adalah makhluk Tuhan yang tidak sempurna. Keterbatasan yang dimiliki manusia inilah yang mendorong untuk saling membantu sesamanya untuk mengatasi kesulitan yang dihadapi. Organisasi kemahasiswaan membentuk kepedulian sosial terhadap lingkungannya, yang ditunjukkan melalui program kerja ormawa yang bersifat sosial, seperti berbagi makanan untuk para pekerja bangunan dan tukang ojek yang dilakukan oleh HMJ Perhotelan. Selain itu, ada juga bakti sosial berupa pengumpulan dan penyaluran pakaian layak pakai yang dilakukan oleh Lembaga Dakwah Kampus Al-Fatihah. Kegiatan-kegiatan tersebut dilakukan oleh mahasiswa sebagai bentuk nyata tanggung jawab sosial kepada sesama dan lingkungan.

13. Tanggung Jawab

Tanggung jawab adalah kesadaran manusia atas tindakan dan perbuatan yang disengaja maupun tidak disengaja dilakukannya. Tanggung jawab sebagai perwujudan kesadaran akan kewajiban. Mahasiswa sebagai penerus estafet kepemimpinan bangsa diharapkan memiliki sikap tanggung jawab dalam melaksanakan setiap tugas yang diberikan.

Dalam mengimplementasikan setiap kegiatan organisasi akan terbentuk sikap tanggung jawab, di mana dalam setiap unit organisasi kemahasiswaan (UKM) terdapat tugas pokok dan fungsinya masing-masing seperti ketua, sekretaris, bendahara dan divisi/seksi. Demikian pula dalam melaksanakan program kerja organisasi, baik jangka panjang, menengah, maupun pendek, masing-masing organisasi selalu membentuk kepanitiaan, sebagaimana ada di UKM Himpa. Meski sudah ada panitia pelaksana 
kegiatan, bukan berarti bahwa pengurus inti organisasi tidak ikut terlibat. Mereka tetap ikut bertanggung jawab penuh terhadap suksesnya program organisasi secara umum. Dalam hal teknis kegiatan, panitia yang lebih banyak bekerja, seperti melakukan koordinasi pencarian anggaran dana, baik anggaran internal (dana DIPA) atau dari sponsor. Selanjutnya, setelah kegiatan selesai, ada juga tanggung jawab dalam wujudu penyusunan laporan kegiatan dan pertanggungjawaban keuangan yang digunakan.

\section{Penutup}

Organisasi kemahasiswaan internal kampus berperan penting dalam membentuk nilai-nilai karakter mahasiswa secara mandiri melalui aktifitas ormawa yang diimplementasikan dalam pelaksanaan program kerja. Dalam pelaksanaan kegiatan inilah, terjadi proses transfer kepemimpinan, komunikasi yang baik, kemandirian, tanggung jawab, kejujuran, sikap menghargai, toleransi, jujur, kreatif, kepedulian, dan kerja sama yang berguna untuk menjadi bekal ketika memasuki dunia kerja (dunia industri). Mengingat organisasi kemahasiswaan memiliki peran penting dalam membentuk nilai-nilai karakter mahasiswa, maka ormawa yang ada di Politeknik Negeri Balikpapan harus dikelola secara maksimal sebagai wahana pengembangan diri mahasiswa dengan mengoptimalkan sumber daya yang dapat mendukung pengembangan minat dan bakat mahasiswa.

\section{Daftar rujukan}

Hendra, Faisal. "Peran Organisasi Mahasiswa Dalam Meningkatkan Mutu Pembelajaran Keterampilan Berbahasa Arab." Arabiyat : Jurnal Pendidikan Bahasa Arab Dan Kebahasaaraban 5, no. 1 (2018): 103-20. https://doi.org/10.15408/a.v5i1.7480.

Herminanto, Sofyan, Implementasi Pendidikan Karakter Melalui Kegiatan Kemahasiswaan. Yogyakarta, 2011.

Hidayah, Yayuk, and Sunarso Sunarso. "Penguasaan Civic Skills Aktivis Badan Eksekutif Mahasiswa (Studi Di Universitas Negeri Yogyakarta)." Harmoni Sosial: Jurnal Pendidikan IPS 4, no. 2 (November 7, 2018): 153-64. https://doi.org/10.21831/hsjpi.v4i2.9862.

IPTEK, Sumber Daya. Undang-Undang Republik Indonesia No.12 Tentang 
Pendidikan Tinggi. Jakarta: Pendidikan Tinggi, Bab I Pasal 1314

Kamaruzzaman, Kamaruzzaman. "ANALISIS KETERAMPILAN KOMUNIKASI INTERPERSONAL SISWA." JURNAL KONSELING GUSJIGANG 2, no. 2 (October 28, 2016). https://doi.org/10.24176/jkg.v2i2.744.

Kementerian Pendidikan Nasional Direktorat Jenderal Pendidikan Tinggi Naskah Akademik Pendidikan Karakter di Perguruan Tinggi. Jakarta: 2011.

Moeloeng, Metodologi Penelitian Kualitatif. Bandung: Remaja Rosda Karya, 2012.

Rachman, Fathor. "Manajemen Organisasi Dan Pengorganisasian Dalam Perspektif Al-Quran Dan Hadith.” Studi Keislaman 1, no. 2 (2015): 291-323.

Rika Sa'diyah. "Pentingnya Melatih Kemandirian Anak." Jurnal KORDINAT 16 (2017): 31-46.

Rohman, Muhamad Asvin Abdur. "Pendidikan Karakter Di Sekolah Menengah Pertama (SMP): Teori, Metodologi Dan Implementasi." QALAMUNA: Jurnal Pendidikan, Sosial, Dan Agama 11, no. 2 (2019): 265-86.

Sanga Lamsari Purba, Leony, and Elisa Natalia Sibarani. "Peran Organisasi Himpunan Mahasiswa Program Studi Dalam Membentuk Karakter Kepemimpinan Calon Guru Kimia." Jurnal Pendidikan Kimia 9, no. 1 (2017): 259-64. https://doi.org/10.24114/jpkim.v9i1.6190.

Sudarsono, Juwono, Keputusan Mentri Pendidikan dan Kebudayaan. Jakarta: Kemdikbud. 1998.

Sugiyono, Metode Penelitian Kuantitatif Kualitatif dan $R \& D$. Remaja Risdakarya: Bandung, 2010.

Ubaidillah, Mujib. "Pembelajaran Berbasis Proyek Untuk Mengembangkan Ensiklopedia Berbasis Bioedupreneurship.” JURNAL PENDIDIKAN SAINS (JPS) 05 (2017): 32-40.

Wardina, Unung Vera, Nizwardi Jalinus, and Lise Asnur. "KURIKULUM PENDIDIKAN VOKASI PADA ERA REVOLUSI INDUSTRI 4.0.” Jurnal Pendidikan 20, no. 1 (March 28, 2019): 82-90. https://doi.org/10.33830/jp.v20i1.240.2019. 